\title{
Functional Hydrolysates from Yellow Fin Tuna Red Meat Using RSM Based Optimization
}

\author{
U. Parvathy ${ }^{1 *}$, P.K. Binsi ${ }^{1}$, C.G. Joshy ${ }^{1}$, A. Jeyakumari ${ }^{2}$, A.A. Zynudheen ${ }^{1}$, \\ George Ninan ${ }^{1}$ and C.N. Ravishankar ${ }^{1}$ \\ ${ }^{1}$ ICAR-Central Institute of Fisheries Technology, Kochi-29, India \\ ${ }^{2}$ Mumbai Research Centre of ICAR-CIFT, Vashi, Navi Mumbai-400703, India \\ *Corresponding author
}

\section{A B S T R A C T}

\section{Keywords}

Tuna red meat, Fish protein hydrolysate, RSM, Functional properties

Article Info

Accepted:

12 October 2018

Available Online:

10 November 2018
The major hydrolytic variables for deriving functional hydrolysates from red meat of yellow fin tuna (Thunnus albacares) were optimized using response surface methodology (RSM). A central composite design (CCD) was employed to obtain the best possible combination of enzyme-substrate ratio $\left(\mathrm{X}_{1}: 0.25-1.5 \%\right)$ and hydrolysis duration $\left(\mathrm{X}_{2}: 30\right.$ $240 \mathrm{~min}$ ) to derive hydrolysates with strongest functional properties with emphasis on protein recovery and sensory acceptability. The experimental data obtained were fitted to second-order and third-order polynomial equation using multiple regression analysis. The optimum hydrolytic conditions for superior functional properties were achieved at an enzyme-substrate ratio (E/S) of $0.34 \%$ for a hydrolysis duration of 30 minutes. The protein recovery of the hydrolysates ranged between $32-50 \%$ which were linearly related $\left(\mathrm{R}^{2}=0.67\right)$ to the degree of hydrolysis. However a few properties of hydrolysate having the same degree of hydrolysis varied significantly and hence, could not be entirely explained based on the degree of hydrolysis.

\section{Introduction}

Globally, tuna resources have high commercial value on account of its demand for thermally processed delicacies. However, the process discards generated during canning operations including the red meat is enormous and accounts to about 50 to $70 \%$ of whole fish (Saidi et al., 2014). Reports by Sutanbawa and Aknes (2006), revealed an estimate of $4,50,000$ million tons per year of processing discards globally from the tuna canning industry. Recovery and conversion of these proteinaceous discards to functional and bioactive hydrolysates is a promisive option for the industry. These hydrolysates containing peptides with distinct range of molecular weight, exhibit superior functional and bioactive properties compared to that of parent protein (He et al., 2013; Binsi et al., 2016). Based on the extent of hydrolysis that the parent protein undergoes, the properties exhibited by the hydrolysates vary considerably.

The attempts for arriving at an optimum degree of hydrolysis (DH) using response surface methodology (RSM) have been made 
extensively on various substrates considering nitrogen recovery (Awuor et al., 2017), bioactive (Wangtueai et al., 2016; Wang et al., 2017) and functional properties (Jamil et al., 2016), as process responses. However, it is well understood that the properties of hydrolysates depend to a large extent on the nature of polypeptide fragments formed, rather than the DH achieved during the hydrolytic process. It is quite obvious that peptides from the same source having the same DH exhibit significant variations in their properties.

At present, the red meat generated during tuna canning operations is mainly converted to low value by-products like animal feed, fertilizers etc.

Hence, the current investigation was intended towards optimizing the effect of hydrolysis variables viz., E/S and hydrolysis duration, using an RSM based central composite design, for extraction of functional hydrolysates from the cannery waste; cooked meat of yellow fin tuna red meat with thrust to maximum protein recovery.

Moreover, a variability range of $\mathrm{DH}$ values with respect to individual properties exhibited by hydrolysates under each hydrolytic conditions was derived by statistical means.

\section{Materials and Methods}

\section{Raw material and chemicals}

Tuna red meat was collected as by-product after canning and retorting from Forstar Frozen Foods Pvt. Ltd., Taloja, Navi Mumbai, which had undergone prior heat treatment at $121{ }^{\circ} \mathrm{C}$ for $1 \mathrm{hr}$. It was initially washed with boiled water $(1: 4(\mathrm{w} / \mathrm{v}))$ for five minutes, pressed and further subjected to washing with cold $0.2 \%$ (w/v) sodium bicarbonate solution $(1: 4(\mathrm{w} / \mathrm{v}))$ for two minutes and pressed to remove excess moisture. This washed meat was used as the starting material for the preparation of protein hydrolysates. Papain enzyme (Hi Media, India) from papaya latex was used for hydrolysis. All other chemicals used for the study were of analytical grade.

\section{Preparation of protein hydrolysate}

The washed red meat was comminuted thoroughly using an electric blender, weighed and added with twice the amount of water for each run. A preliminary trial was carried out for optimizing the temperature of hydrolysis considering degree of hydrolysis, protein recovery and proteolytic activity as process variables with major parameters viz. $\mathrm{pH}$, enzyme: substrate ratio (E/S) and hydrolysis time as constant (Data not shown).

Further experiments based on the statistical design were performed in a shaking water bath (Shaking bath, Neolab Instruments, Mumbai, India) with continuous agitation at this constant optimised temperature. On completion of the process, the hydrolysis was terminated by heating the solution to $85-90{ }^{\circ} \mathrm{C}$ for $15-20 \mathrm{~min}$. The resultant solution was cooled and centrifuged at $8000 \mathrm{~g}$ at $10^{\circ} \mathrm{C}$ for 20 min (K-24A, Remi Instruments, Mumbai) to obtain supernatant which was further used for analysis.

\section{Experimental design}

Response Surface Methodology with a central composite design (CCD) with two independent variables at three levels was chosen based on the results of preliminary experiments. The input factors were enzymesubstrate ratio $(\mathrm{E} / \mathrm{S})\left(\mathrm{X}_{1}\right)$ and hydrolysis time $\left(\mathrm{X}_{2}\right) . \mathrm{pH}$ was maintained constant and optimized hydrolysis temperature was adopted. Single and combined effects of the variables on the responses were studied by formulating thirteen experimental runs. The responses included protein recovery, foaming, 
emulsifying, oil absorption and sensory properties for functionality optimization. Contour plots and response surface graphs were generated by the predictive model to envisage the critical points and the effectiveness of each factor. Desirability score was computed for multi response optimization of response variables for functionality of hydrolysate with emphasis to protein recovery and the optimum combination of enzyme substrate ratio and hydrolysis time was selected.

\section{Determination of proximate composition}

Proximate composition of tuna red meat before and after treatment was estimated as per AOAC (2012). Protein content of tuna red meat and hydrolysates were estimated by kjelhdahl method.

\section{Determination of Degree of Hydrolysis (DH)}

Degree of hydrolysis was estimated as per the methodology described by Hoyle and Merritt (1994). Briefly, degree of hydrolysis was computed as

$10 \%$ TCA soluble $\mathrm{N}_{2}$ in the sample

$\% \mathrm{DH}=$ - Total $^{\mathrm{N}_{2}}$ in the sample

\section{Determination of protein recovery}

Protein recovery in hydrolysate was defined as the percentage of protein obtained during the extraction process to the total amount of protein in raw material and was calculated as follows:

Protein in hydrolysate $\mathrm{x}$ Volume of hydrolysate Recovered protein $(\%)=$--------------- x 100

Weight of red meat taken $x$ Amount of protein in red meat

\section{Determination of functional properties}

\section{Foaming properties}

Foaming capacity and stability of fish protein hydrolysate were determined by the method described by Sathe and Salunkhe (1981). Protein solution $(1.0 \%)$ was homogenized (230 VAC T-25 digital Ultra-turrax, IKA, India) at a speed of $16,000 \mathrm{rpm}$ for $2 \mathrm{~min}$ to entrap air and foaming capacity was determined instantly whereas foam stability after a time period of 3 minutes as:

Foaming capacity/stability $(\%)=[(\mathrm{A}-\mathrm{B}) / \mathrm{B}]$ $\mathrm{x} 100$

Where $\mathrm{A}$ is the volume immediately after whipping (foam capacity) and after $3 \mathrm{~min}$ standing (foam stability); $\mathrm{B}$ is the volume before whipping.

\section{Emulsifying properties}

Emulsifying properties were determined according to the method of Pearce and Kinsella (1978). A pre-mix containing 1\% protein solution and vegetable oil $(3: 1(\mathrm{v} / \mathrm{v}))$ were homogenized (230 VAC T-25 digital Ultra-turrax, IKA, India) for a period of $1 \mathrm{~min}$ at 20,000 rpm and an aliquot of the emulsion $(50 \mu 1)$ was carefully taken from the bottom of the container at 0 and $10 \mathrm{~min}$ after homogenization. Further it was mixed with 5 $\mathrm{ml}$ of $0.1 \%$ sodium dodecyl sulphate (SDS) solution and the absorbance measured at 500 nm (Lambda 25 UV/Vis, Perkin Elmer Life and Analytical Sciences, Singapore) immediately $\left(\mathrm{A}_{0}\right)$ and $10 \mathrm{~min}\left(\mathrm{~A}_{10}\right)$ after emulsion formation to evaluate the emulsifying activity index (EAI) and the emulsion stability index (ESI) as:

$$
\operatorname{EAI}\left(\mathrm{m}^{2} / \mathrm{g}\right)=\frac{2 \times 2.303 \times \mathrm{A}_{0}}{0.25 \times \text { wt of protein }}
$$


$\operatorname{ESI}(\min )=\frac{\mathrm{A}_{10} \mathrm{x} \Delta \mathrm{t}}{\Delta \mathrm{A}}$

Where $\Delta \mathrm{A}=\mathrm{A}_{0}-\mathrm{A}_{10}$ and $\Delta \mathrm{t}=10 \mathrm{~min}$

\section{Oil absorption capacity}

OAC of sample was determined as the volume of edible oil held by a known quantity of the material as per the method of Shahidi et al., (1995). A $0.5 \mathrm{~g}$ sample with oil added $(10 \mathrm{ml})$ was vortexed (Expo Hitech, India) for $30 \mathrm{sec}$ following centrifugation (K-24A, Remi Instruments, Mumbai) at $2800 \mathrm{~g}$ for $25 \mathrm{~min}$.

The free oil was decanted and the OAC was determined by weight difference ( $g$ of oil per gram of sample).

\section{Sensory property}

Bitterness of hydrolysate was sensorily evaluated by 10 trained panellists as per Nilsang et al., (2005) with modifications. The panelists were trained using caffeine solution as a standard which was presented in different reference concentrations for anchoring the bitterness scale. A 10-cm line scale anchored from "no bitterness" (as 1) to "extreme bitterness" (10) was defined.

Panellists evaluated bitter taste of hydrolysate samples in comparison with the standard reference using the designed scale.

\section{Statistical Model Development}

The CCD in the experimental design consisted of 13 experimental points conducted in random order ( 5 factorial points, 5 axial points and 3 center points) (Table 1). Second order/ quadratic and third order/cubic regression models were fitted to the response variables as a function of input variables using the polynomial equation:
Second order regression: $Y=\beta_{0}+\beta_{\mathrm{i}} X_{\mathrm{i}}+$ $\beta_{\mathrm{ij}} \mathrm{X}_{\mathrm{i}} \mathrm{X}_{\mathrm{j}}+\beta_{\mathrm{ii}} \mathrm{X}_{\mathrm{i}}^{2}, \mathrm{i} \neq \mathrm{j}=1,2$

Third order regression: $Y=\beta_{0}+\beta_{\mathrm{i}} X_{\mathrm{i}}+\beta_{\mathrm{ij}} \mathrm{X}_{\mathrm{i}} \mathrm{X}_{\mathrm{j}}$ $+\beta_{\mathrm{ii}} X_{\mathrm{i}}^{2}+\beta_{\mathrm{iji}} \mathrm{X}_{\mathrm{i}}^{2} \mathrm{X}_{\mathrm{j}}, \mathrm{i} \neq \mathrm{j}=1,2$

Y being the response; $\beta_{0}$ : the offset term; $\beta_{\mathrm{i}}$, $\beta_{\mathrm{ij}}, \beta_{\mathrm{ii}}$ and $\beta_{\mathrm{iij}}$ being the regression coefficients and $\mathrm{Xi}$ and $\mathrm{Xj}$, the levels of the independent variables. The performance of the fitted model was assessed by Coefficient of determination $\left(\mathrm{R}^{2}\right)$ and mean square error (MSE). Significance of the regression coefficients was determined at $5 \%$ level of significance $(\mathrm{p}<0.05)$. A software Design expert 7.0 was used to fit the models.

\section{Results and Discussion}

\section{Proximate composition of raw material mince}

The proximate composition of tuna red meat mince before and after water washing was assessed. Tuna red meat was initially washed with boiled water and subsequently with $0.2 \%$ cold sodium bicarbonate solution to remove excess of fat and pigments. Previously, Bhaskar et al., (2008) suggested a prior hot water washing $\left(85^{\circ} \mathrm{C}\right.$ for $\left.20 \mathrm{~min}\right)$ for catla visceral waste followed by centrifugation to increase the stability of the hydrolysates towards lipid oxidation.

The washing process increased the moisture content of mince by $3.38 \%(67.11 \pm 0.02$ to $70.49 \pm 0.48 \%$ ), with a proportional decrease in the protein content from $28.19 \pm 0.62$ to $24.98 \pm 0.24 \%$. This was also accompanied by a significant $(\mathrm{p}<0.05)$ reduction in the fat $(2.22 \pm 0.02 \%$ to $1.4 \pm 0.17 \%)$ and ash content $(1.43 \pm 0.06$ to $0.64 \pm 0.01 \%)$ of the mince to almost half of its initial value. The higher moisture content observed in the washed mince might be either due to the hydration of myofibrillar proteins or may be a 
relative increase associated with the loss of water soluble proteins, fat and mineral during the leaching process.

\section{Optimization of hydrolysis parameters}

The optimisation of hydrolytic parameters was carried out in two steps. Initially, the temperature for the hydrolysis was optimised keeping E/S, $\mathrm{pH}$ and time as constant, followed by the optimisation of $\mathrm{E} / \mathrm{S}\left(\mathrm{X}_{1}\right)$ and hydrolysis time $\left(\mathrm{X}_{2}\right)$ under optimum conditions of temperature and $\mathrm{pH}$. The response variables considered for optimising the process temperature were degree of hydrolysis, protein recovery and proteolytic activity. All the variables were found to be increasing upto $60^{\circ} \mathrm{C}$, and thereafter showed a decreasing trend. Hence, the subsequent hydrolysis experiment was carried out at a single temperature of $60^{\circ} \mathrm{C}$. Similarly, the $\mathrm{pH}$ opted for the hydrolysis process was the initial $\mathrm{pH}$ of the substrate (washed mince), ie $\mathrm{pH}$ 6.5, since it falls within the optimal $\mathrm{pH}$ range of papain enzyme as indicated by the manufacturer (pH 6-7).

\section{RSM based optimisation of process variables}

The influence of $\mathrm{E} / \mathrm{S}\left(\mathrm{X}_{1}\right)$ and hydrolysis time $\left(\mathrm{X}_{2}\right)$ under optimum conditions of temperature and $\mathrm{pH}$ by papain on cooked tuna red meat protein was determined using central composite design. The response variables considered for optimising the derivation of functional hydrolysate were foaming, emulsifying and oil absorption properties together with sensory property. For optimization, protein recovery was also given special emphasis. A multiple regression analysis technique was performed to determine all the coefficients of linear $\left(X_{1}\right.$, $\left.\mathrm{X}_{2}\right)$, quadratic $\left(\mathrm{X}_{1}^{2}, \mathrm{X}_{2}^{2}\right)$ and interaction $\left(\mathrm{X}_{1} \mathrm{X}_{2}\right)$ terms to fit a full response surface model for the responses.

\section{Changes in DH}

Previously, several authors have suggested degree of hydrolysis as the major contributor to the specific properties exhibited by the peptides (Ren et al., 2008; Taheri et al., 2013). However, peptides derived from the same source having similar DH values quite often vary in their properties. Authors like Amarowicz (2008) have suggested that the presence of specific peptides liberated from protein as well as the amount of free amino acids to be important in determination of bioactive properties of protein hydrolysate. Hence, in the present study, DH was not included in the RSM analysis matrix. However the $\mathrm{DH}$ values were independently determined for each hydrolytic conditions mentioned in the matrix. Further, the changes in the individual properties were discussed in relation to the changes in $\mathrm{DH}$ values.

\section{Variations in protein recovery}

The protein recovery was considered as a response variable for both the optimisation designs, as it adds to the economics of the hydrolysis operation. The variations in this response during the hydrolytic process were best explained by second order response surface model ( $\mathrm{p}<0.05$ ) (Fig. 1a) with an $\mathrm{R}^{2}$ value of 0.98 and MSE of 1.78 using the equation:

$\mathrm{PR}=27.30+20.79 \mathrm{X}_{1} *+0.03 \mathrm{X}_{2}-3.24 \mathrm{E}-003$ $\mathrm{X}_{1} \mathrm{X}_{2}-4.99 \mathrm{X}_{1}^{2}-8.52 \mathrm{E}-005 \mathrm{X}_{2}^{2}$

The adjusted $\mathrm{R}^{2}$ of the fitted model was 0.96 and analysis of lack of fit was found to be insignificant $(\mathrm{p}>0.05)$ indicating the suitability of the model. The precision measures of $\mathrm{S} / \mathrm{N}$ (signal to noise ratio) was greater than 4 (17.797) indicating adequate model discrimination (Myers et al., 2009). The linear effect of $\mathrm{X}_{1}$ on nitrogen recovery was found to have a statistically significant 
effect $(p<0.05)$ with high regression coefficient value of 20.79 , whereas that of $X_{2}$ was marginal. The quadratic effects of both the variables showed negative values indicating that the protein recovery reaches a threshold level at certain value of $\mathrm{E} / \mathrm{S}$ and time, thereafter showing a reduction in the rate of increase. It is generally agreed that the high E/S ratio and longer hydrolysis period favours higher protein recovery (Diniz and Martin, 1998; Liaset et al., 2002). In the present study, protein recovery varied directly with the degree of hydrolysis $\left(\mathrm{R}^{2}=0.67\right)$ of up to $25 \%$ and thereafter showed a slightly decreasing or more or less similar values (Fig. 1b). However for similar $\mathrm{DH}$, variations were observed in this response ranging on an average from $5-9$ $\%$.

It was also noticed that as indicated in quadratic equation, E/S had more influence than time with higher $\mathrm{E} / \mathrm{S}$ giving more recovery of protein from substrate than the period of hydrolysis. From the regression coefficients of statically fitted models observed in the present study, it may be inferred that increasing the concentration of enzyme is more beneficial in getting higher protein recovery than increasing the duration of hydrolysis beyond a $\mathrm{DH}$ value of $25 \%$.

\section{Variations in functional properties}

\section{Foaming properties}

Foaming properties are usually expressed in terms of foaming capacity and foam stability. Second order regression model with an $\mathrm{R}^{2}$ value of 0.86 explained the changes in foaming capacity of hydrolysate under different hydrolytic conditions. The regression coefficient values of fitted quadratic model for foaming properties were:

$\mathrm{FC}=166.63+33.05 \mathrm{X}_{1}+0.04 \mathrm{X}_{2}^{*}-0.13$ $\mathrm{X}_{1} \mathrm{X}_{2}-8.03 \mathrm{X}_{1}^{2}-6.12 \mathrm{E}-004 \mathrm{X}_{2}^{2}$
The FC values showed strong positive linearity with $\mathrm{X}_{1}$ (Fig. 1c), however the quadratic effect showed negative values. In the case of $\mathrm{X}_{2}$, the linear effect on protein recovery was minimum, however was found to be statistically significant $(\mathrm{p}<0.05)$. This essentially means that, FC values increased initially with increase in E/S ratio to reach a threshold value, and thereafter decreased with every unit of increase in E/S ratio. Foaming capacity was higher at lower DH (Fig. 1d) and it ranged from 122 - 205\% under different conditions of E/S ratio and hydrolysis time which in turn influenced the DH. For similar $\mathrm{DH}$ it exhibited wide variations in the property ranging from 35 - $60 \%$, on an average.

Similar to protein recovery, E/S had higher influential role than time and hence for similar $\mathrm{DH}$, the hydrolytic condition with higher E/S gave better foaming capacity for the derived hydrolysate. Variations in the foam stability were explained by quadratic regression model with an $\mathrm{R}^{2}$ of 0.96 . The foam stability values showed strong negative linear effect with $\mathrm{X}_{1}$ while giving a positive quadratic effect, whereas both linear and quadratic effect was found to be marginal for $X_{2}$. Similarly, the interaction effects of both $\mathrm{X}_{1}$ and $\mathrm{X}_{2}$ on foaming properties were also minimum.

$\mathrm{FS}=177.75-155.98 \mathrm{X}_{1} *-0.23 \mathrm{X}_{2} *+0.48$ $\mathrm{X}_{1} \mathrm{X}_{2} *+26.30 \mathrm{X}_{1}^{2}-1.59 \mathrm{E}-003 \mathrm{X}_{2}^{2}$

The results suggested a drastic reduction in FS with increase in the concentration of enzyme upto certain degree of hydrolysis, thereafter showing constant values. There was a general trend of decrease in the foaming properties with increase in DH (Table 1). However, it was observed that for similar range of $\mathrm{DH}$, distinctly different response were exhibited, which further suggest that the nature of peptides formed under different hydrolytic conditions play a major role in determining the final properties of hydrolysate. 


\section{Int.J.Curr.Microbiol.App.Sci (2018) 7(11): 1462-1474}

Table.1 Experimental design and responses of the dependent variables to the hydrolysis conditions

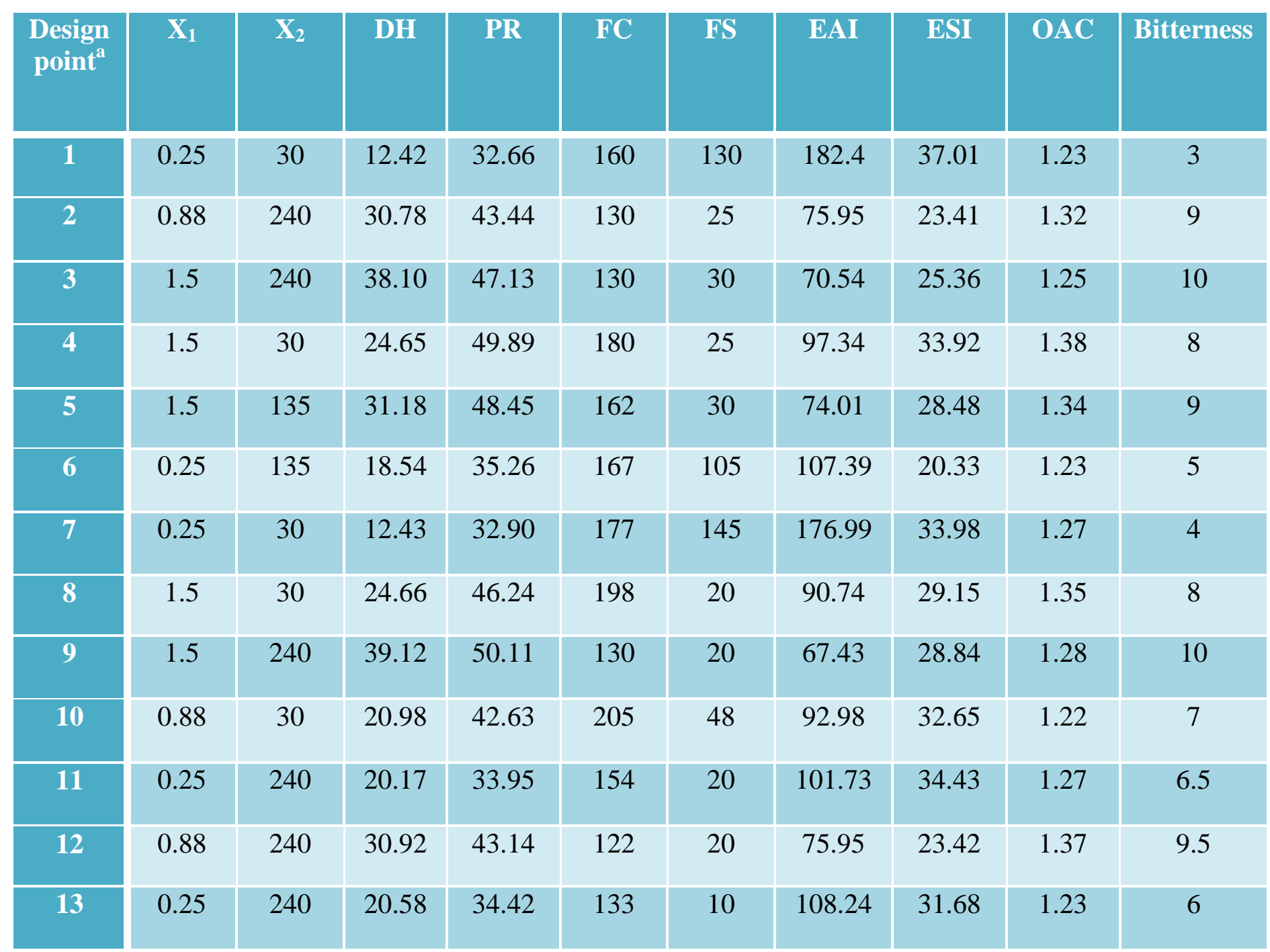

${ }^{\mathrm{a}}$ Experiments were run at random, $\mathrm{X}_{1}$ : Enzyme-substrate ratio $(\%), \mathrm{X}_{2}$ : Hydrolysis time, DH: Degree of hydrolysis (\%), PR: Protein recovery (\%), FC: Foaming Capacity (\%), FS: Foam Stability (\%), EAI: Emulsifying Activity Index (m²/g), ESI: Emulsion Stability Index (min), OAC: Oil Absorption Capacity (g/g) 
Fig.1 Variations in protein recovery (\%) a. in response to enzyme-substrate ratio and hydrolysis time; b. in relation to DH; Variations in Foaming capacity (\%) c. in response to enzyme-substrate

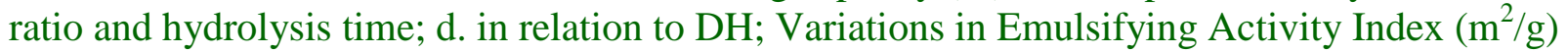
e. in response to enzyme-substrate ratio and hydrolysis time; f. in relation to $\mathrm{DH}$; Variations in Oil Absorption Capacity (g/g) g. in response to enzyme-substrate ratio and hydrolysis time; $\mathrm{h}$. in relation to DH; Variations in Bitterness i. in response to enzyme-substrate ratio and hydrolysis time; $\mathrm{j}$. in relation to $\mathrm{DH}$
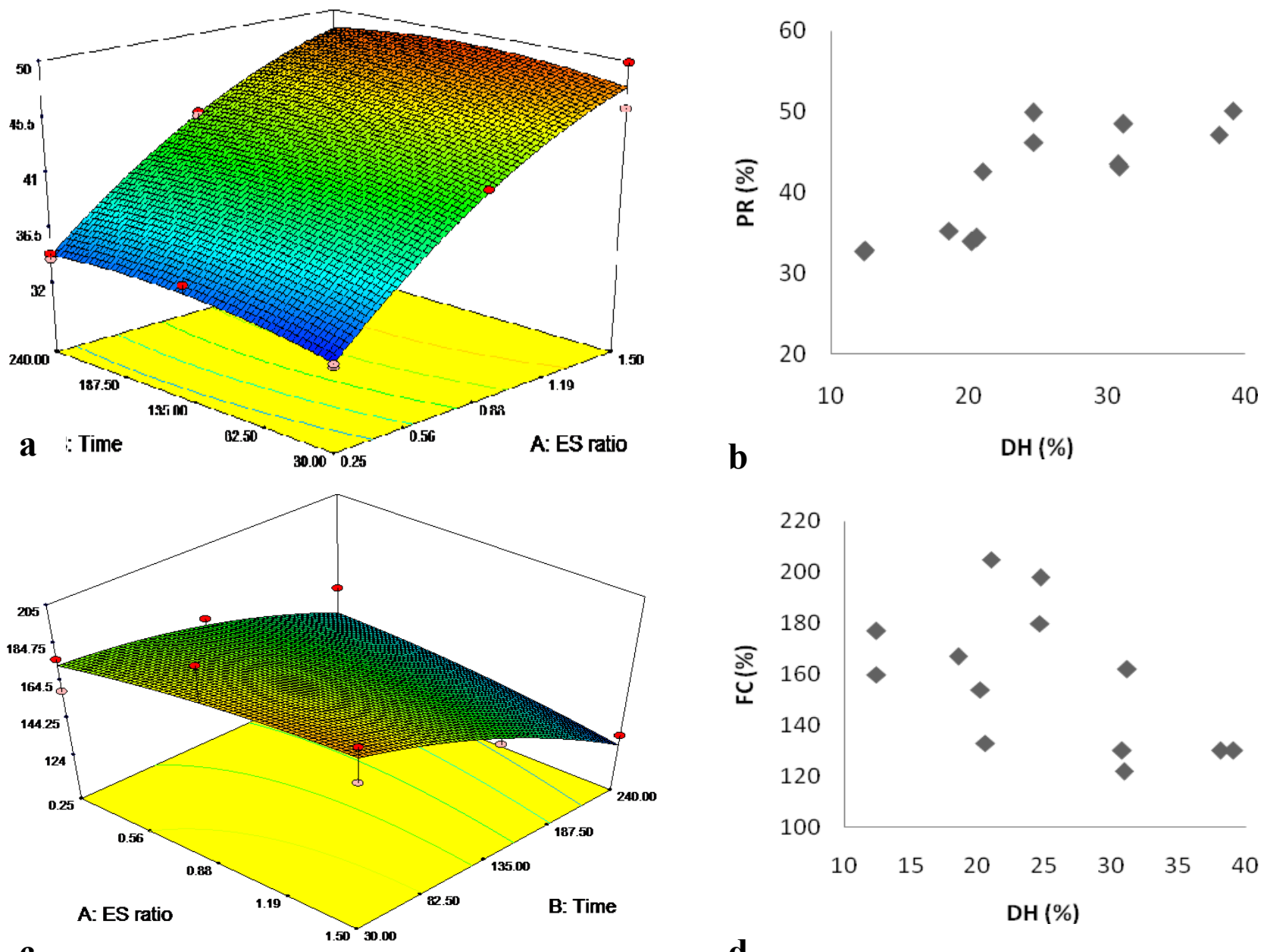

c
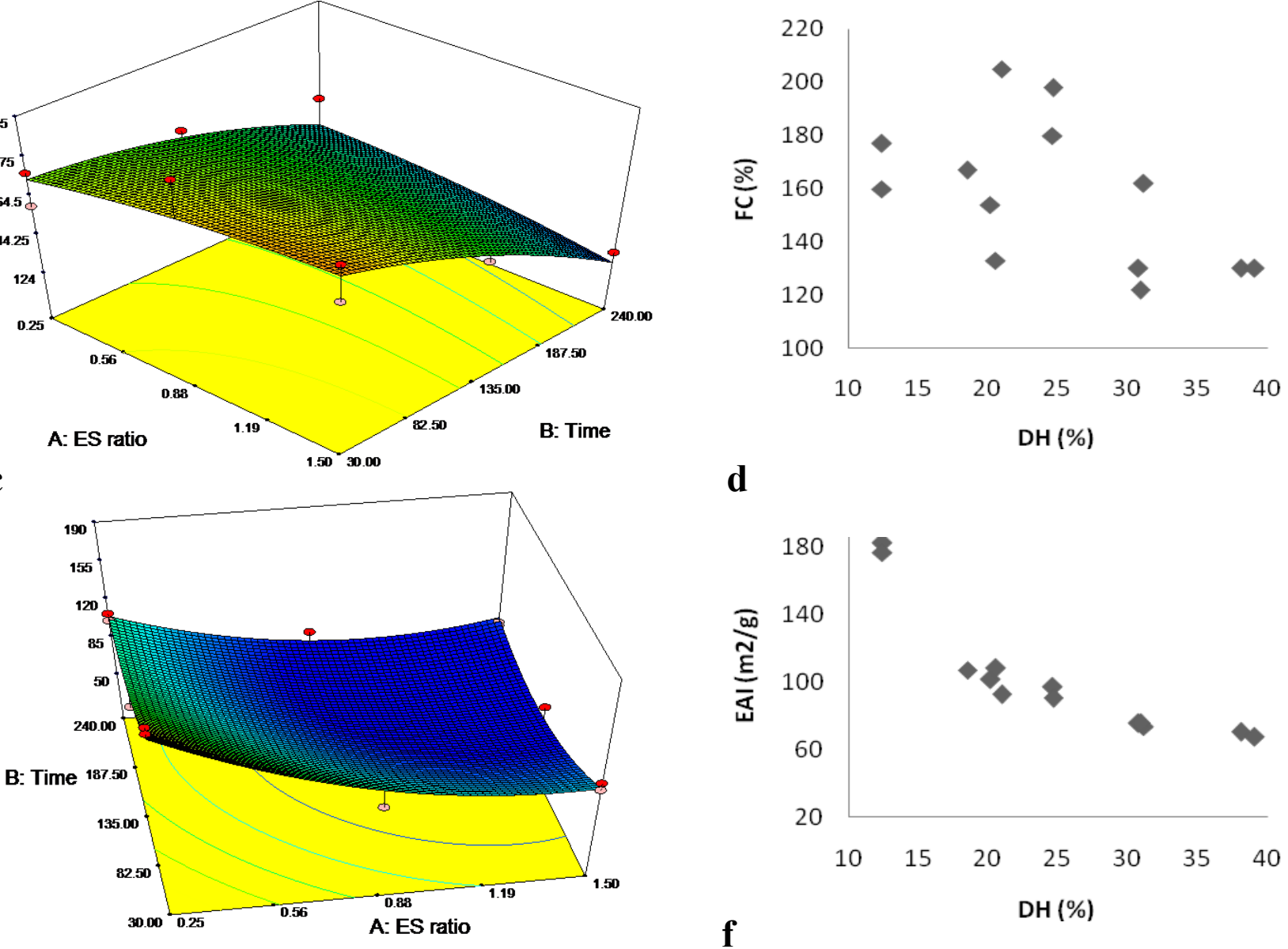

d

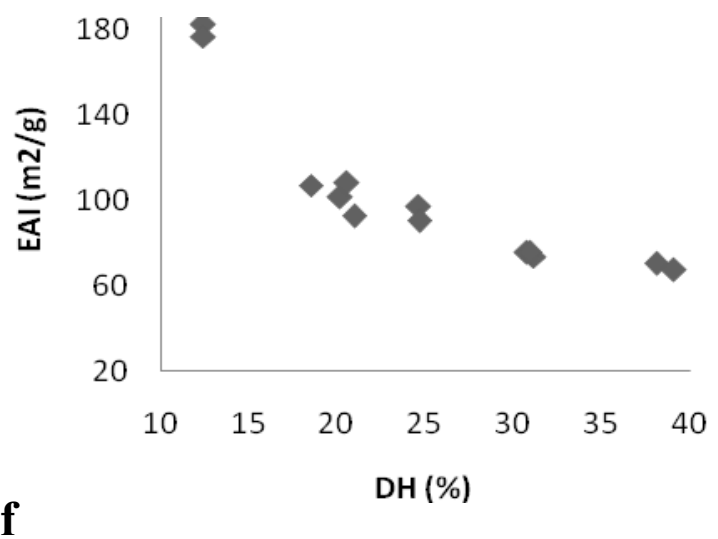



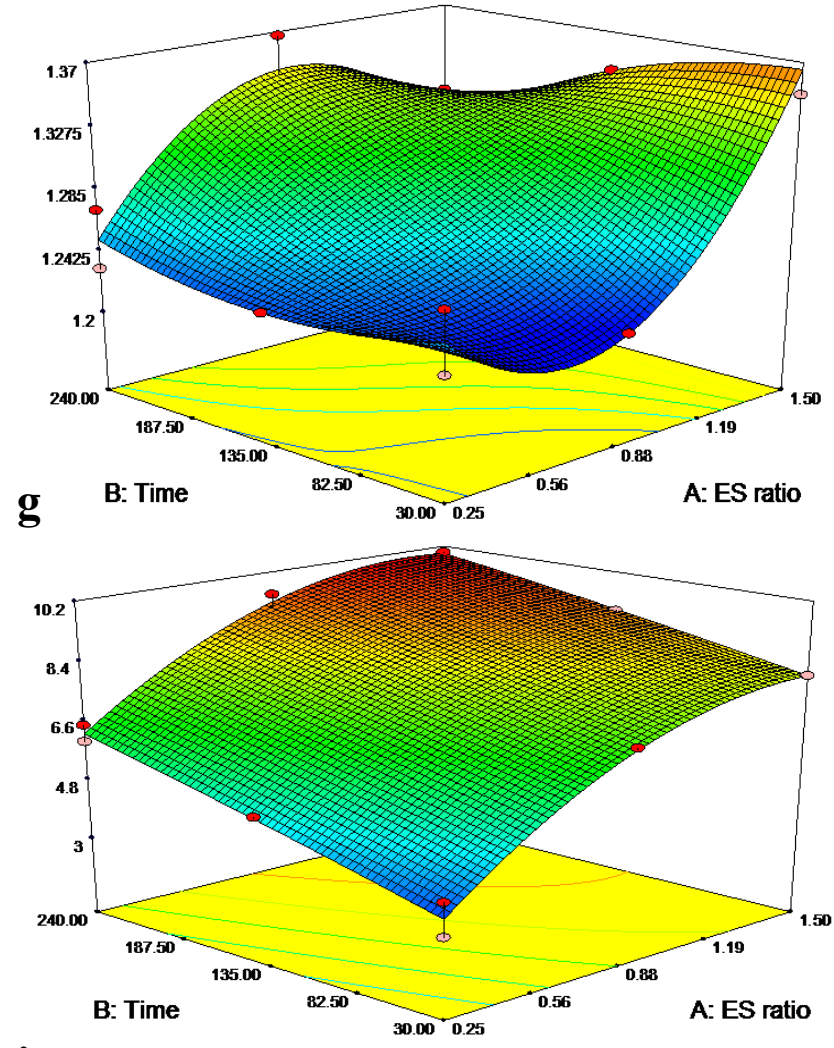

i

\section{Emulsifying properties}

Second order regression model was best fitted for explaining the changes in EAI. The high coefficient of determination $\left(\mathrm{R}^{2}=0.95\right)$ indicated that the model as fitted can explain $94.6 \%$ of the EAI variability (Fig. 1e). Linear, second order and interaction of both $\mathrm{X}_{1}$ and $\mathrm{X}_{2}$ were found to be significant $(\mathrm{p}<0.05)$ in influencing the variations of this response.

$\mathrm{EAI}=-235.98-173.63 \mathrm{X}_{1} *-0.88 \mathrm{X}_{2} *+$ $0.19 \mathrm{X}_{1} \mathrm{X}_{2} *+59.29 \mathrm{X}_{1}{ }^{2} *+1.93 \mathrm{E}-003 \mathrm{X}_{2}{ }^{2}$

Both the factors were inversely related to the changes in response as indicated by negative regression coefficient. However linear as well as quadratic terms of $\mathrm{X}_{1}$ was observed to be more important for response variations indicating a regression coefficient of 173.63 and 59.29 , respectively while $X_{2}$ showed only a marginal influence on EAI.
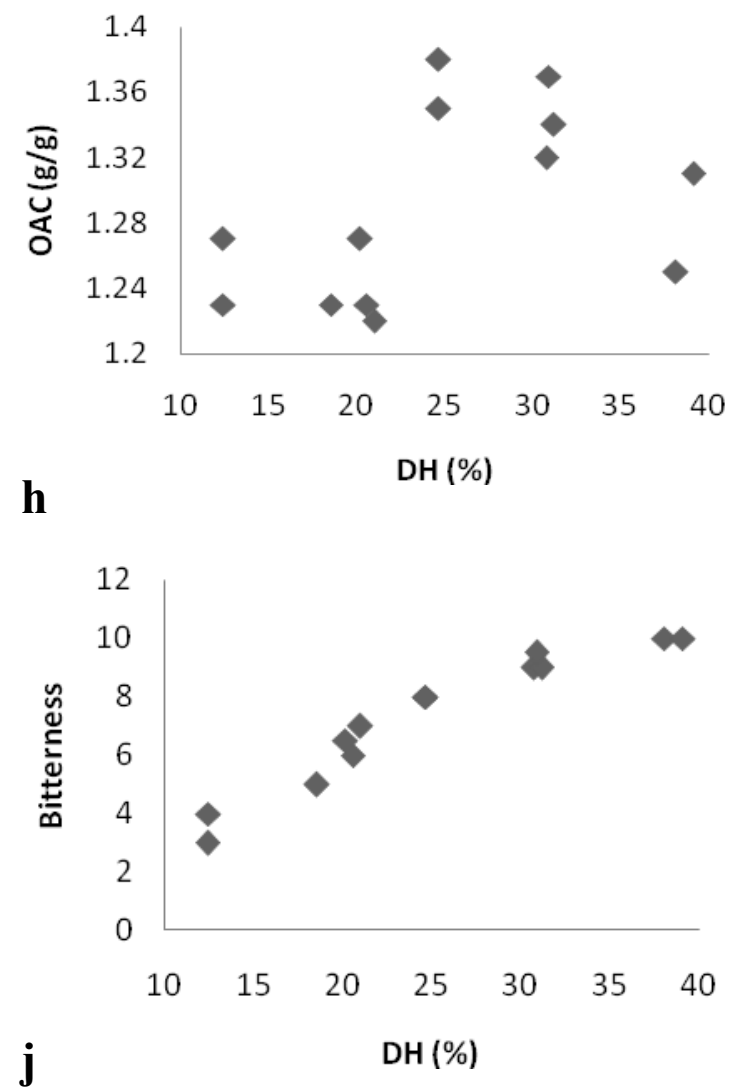

ESI was explained using cubic model with an $\mathrm{R}^{2}$ of 0.92 . An adequate precision of 8.510 , indicating the signal to noise ratio was observed and as the value was greater than the desired value of 4 , the present model indicated its fitness for explaining the variations in ESI. The linear terms of $\mathrm{X}_{1}$ and $\mathrm{X}_{2}$ as well as second order of $\mathrm{X}_{2}$ and interaction of linear terms $X_{1}$ and second order of $\mathrm{X}_{2}$ were the significant terms $(\mathrm{p}<$ 0.05 ). $X_{1}$ and $X_{2}$ were equally influential for the variations in this response however, $\mathrm{X}_{1}$ was directly related while $X_{2}$ was inversely related to ESI in hydrolysate.

The equation explaining the variations in ESI in terms of coded factors was:

$\mathrm{ESI}=20.66+4.08 \mathrm{X}_{1}{ }^{*}-4.62 \mathrm{X}_{2}{ }^{*}-0.50$ $\mathrm{X}_{1} \mathrm{X}_{2}+3.75 \mathrm{X}_{1}^{2}+7.39 \mathrm{X}_{2}^{2 *}+2.90 \mathrm{X}_{1}^{2} \mathrm{X}_{2}-$ $6.55 \mathrm{X}_{1} \mathrm{X}_{2}^{2} *$ 
Both EAI and ESI indicated significant reduction in values with progress of hydrolysis, with the highest values at a $\mathrm{DH}$ of $12.42 \%$ which is the lowest $\mathrm{DH}$ obtained during the study, corresponding to $\mathrm{X}_{1}$ of 0.25 $\%$ and $\mathrm{X}_{2}$ of $30 \mathrm{~min}$ (Fig. 1f, Table 1). In general, the emulsifying properties showed marked decrease in the values above $\mathrm{DH}$ value of $20 \%$. EAI exhibited an inverse relation with $\mathrm{DH}\left(\mathrm{R}^{2}=0.75\right)$ and variations of up to $12 \mathrm{~m}^{2} / \mathrm{g}$ were observed for similar $\mathrm{DH}$ generated through different combinations of $X_{1}$ and $X_{2}$. However the variations in ESI for similar DH ranged from $0.5 \mathrm{~min}-5 \mathrm{~min}$. Kristinsson and Rasco (2000) stated to have exceptional emulsifying activity and stability for hydrolysate produced under limited degree of hydrolysis. Similar reports of greater emulsifying capacity and emulsion stability were noticeable when DH was low for salmon byproduct hydrolysate (Gbogouri et al., 2004) and sardine hydrolysate (Quaglia and Orban, 1990).

\section{Oil Absorption Capacity}

OAC is related to the surface hydrophobicity in hydrolysates which is facilitated by the hydrolysis process. Cubic model with an $\mathrm{R}^{2}$ of 0.88 best explained the variations in this response (Fig. 1g). All the influencing variables $X_{1}$ and $X_{2}$ had a marginal effect with positive correlation. However linear terms of $\mathrm{X}_{2}$ as well as interaction effect of second order terms of E/S and linear terms of hydrolysis time $\left(\mathrm{X} 1^{2} \mathrm{X}_{2}\right)$ were significant $(\mathrm{p}<$ 0.05). The model was fitted using the equation in terms of coded factor as:

$\mathrm{OAC}=1.28+0.056 \mathrm{X}_{1}+0.063 \mathrm{X}_{2} *-0.023$ $\mathrm{X}_{1} \mathrm{X}_{2}+4.731 \mathrm{E}-003 \mathrm{X}_{1}{ }^{2}-2.388 \mathrm{E}-003 \mathrm{X}_{2}{ }^{2}-$ $0.084 \mathrm{X}_{1}^{2} \mathrm{X}_{2} *-0.019 \mathrm{X}_{1} \mathrm{X}_{2}^{2}$

During hydrolysis, the variation in OAC was minimum ranging between $1.23-1.38 \mathrm{~g} / \mathrm{g}$ with the changes in factors viz., $\mathrm{X}_{1}$ or $\mathrm{X}_{2}$
(Table 1). Unlike the foaming and emulsifying properties, higher OAC value was observed at a slightly higher $\mathrm{DH}$ value of $24.65 \%$, however further decreased above DH value of $30 \%$. The correlation studies of OAC with $\mathrm{DH}$ also substantiated varying response with no definite increase or decrease (Fig. 1h). Variations in the hydrophobicity of the polypeptide fragment formed during hydrolysis might have resulted in wide variations in OAC exhibited by the hydrolysate derived under similar degree of hydrolysis. Similar to this, DH ranging between $2.4-2.8 \mathrm{ml} / \mathrm{g}$ was reported in cobia frame hydrolysates by Amiza et al., (2012) and an OAC ranging between $0.9-1.4 \mathrm{~g} / \mathrm{g}$ was reported in hake by-product hydrolysates by Pires et al., (2012).

\section{Sensory property}

Although enzymatic hydrolysis of protein develops desirable functional properties, it has the disadvantage of generating bitterness which is identified as a major hindrance in the utilization and commercialization of bioactive FPH (Kim and Wijesekara, 2010). The mechanism of bitterness is not very clear, but it is widely accepted that hydrophobic amino acids are one of the major contributors. Of the many techniques suggested to reduce or mask bitterness in hydrolysates, strict control of any hydrolysis experiment and termination at low degree of hydrolysis is desirable to prevent the development of bitter taste and retention of functional properties (Adler-Nissen, 1986; Saha and Hayashi, 2001).Quadratic regression model $(\mathrm{p}<0.05)$ with a high determination coefficient $\left(\mathrm{R}^{2}=0.99\right)$ and an MSE of 0.11 was fitted to predict the trends of bitterness of hydrolysate generated with various combinations of $\mathrm{X}_{1}$ and $\mathrm{X}_{2}$. The adjusted $\mathrm{R}^{2}$ value of 0.98 and predicted $R^{2}$ value of 0.96 which were in reasonable agreement, further confirms the high significance of the fitted model. Linear terms of both $\mathrm{X}_{1}$ and $\mathrm{X}_{2}$ as well 
as second order term of $\mathrm{X}_{1}$ were significant terms $(\mathrm{p}<0.05)$ with $\mathrm{X}_{1}$ being more influential in determining the variations of bitterness while hydrolysis time $\left(\mathrm{X}_{2}\right)$ had a marginal influence for the same extent of hydrolysis.

Bitterness $=1.07+8.85 \mathrm{X}_{1} *+0.02 \mathrm{X}_{2}^{*}-$ 2.86E-003 $\mathrm{X}_{1} \mathrm{X}_{2}-2.96 \mathrm{X}_{1}^{2 *}-5.67 \mathrm{E}-006 \mathrm{X}_{2}^{2}$

However beyond an extended limit, $\mathrm{X}_{1}$ had minimum influence in bitterness generation in the hydrolysates as indicated by a negative coefficient for quadratic regression terms. Response surface graphs generated by the predictive model clearly indicated the trends in the bitterness with $X_{1}$ and $X_{2}$ (Fig. 1i).

The observed trend was well in agreement with the changes in $\mathrm{DH}$, as indicated by the $\mathrm{R}^{2}(0.915)$ value of correlation graph where bitterness increased almost linearly with $\mathrm{DH}$ upto a value of $30 \%$ and thereafter showed a stagnating trend (Fig. 1j). The variations between the samples having same $\mathrm{DH}$ obtained through different combinations of $\mathrm{X}_{1}$ and $X_{2}$ were minimum with a slightly higher influence for $E / S$ in the generation of bitterness than period of hydrolysis which was substantiated from regression equation for this response.

From above observations, it may be inferred that optimum conditions for extracting functional peptides were; $\mathrm{E} / \mathrm{S}$ of $0.34 \%$ for a duration of 30 minutes at $60^{\circ} \mathrm{C}$ and $\mathrm{pH} 6.5$. The maximum desirability score obtained for this condition was 0.49 , when protein recovery was included as response variable, and 0.70 without protein recovery. Further, all the response variables of the final products were validated. The experimental and predicted values were within the range and did not differ statistically at 5\% level (data not shown), thus confirming the reliability of the optimised condition.
The objective of the study was to identify the optimised process conditions for deriving tuna protein hydrolysate having desirable range of functional properties by suitable statistical models. Moreover, emphasis was given to assess the dependency of these properties on degree of hydrolysis by comparing the values of hydrolysates obtained through different hydrolytic conditions, but having similar DH values. It was clear from the results that, for the parameters analysed, enzyme-substrate ratio $\left(\mathrm{X}_{1}\right)$ was more influential in explaining the response variations than hydrolysis time. Correlation studies between the degree of hydrolysis and responses recommended that though a general trend can be suggested, peptide properties can't be entirely explained based on the degree of hydrolysis but rather on the nature of polypeptide fragment formed under different hydrolytic conditions.

\section{Acknowledgements}

The authors thank the Indian Council of Agricultural Research (ICAR), New Delhi for the financial support. First author also thank all scientific, technical and supporting staffs of Mumbai Research Centre, ICAR-CIFT for the support rendered during the study.

\section{References}

Adler-Nissen, J. 1986. Enzymic Hydrolysis of Food Proteins. Barking, UK: Elsevier Applied Science Publishers.

Amarowicz, R. 2008. Antioxidant activity of protein hydrolysates. Eur. J. Lipid Sci. Technol. 110(6): 489-490.

Amiza, M. A., Kong, Y. L., and Faazaz, A. L. 2012. Effects of degree of hydrolysis on physicochemical properties of cobia (Rachycentron canadum) frame hydrolysate. Int. Food Res. J. 19(1): 199-206. 
AOAC. 2012. Official Methods of Analysis. Association of Official Analytical Chemists. (19th Ed.), Washington DC.

Awuor, O. L., Kirwa, M. E., Jackim, M.F., and Betty, M. 2017. Optimization of alcalase hydrolysis conditions for production of dagaa (Rastrineobola argentea) hydrolysate with antioxidative properties. Ind. Chem. 3: 122 doi: 10.4172/2469-9764.1000122.

Bhaskar, N., Benila, T., Radha, C., and Lalitha. R. G. 2008. Optimization of enzymatic hydrolysis of visceral waste proteins of catla (Catla catla) for preparing protein hydrolysates using a commercial protease. Biores. Technol. 99: 335-343.

Binsi, P. K., Viji, P., Panda, S. K., Mathew, S., Zynudheen, A. A, and Ravishankar, C. N. 2016. Characterisation of hydrolysates prepared from engraved catfish (Nemapteryx caelata) roe by serial hydrolysis. J. Food Sci. Technol. 53(1):158-170.

Diniz, F. M., and Martin, A. M. 1998. Influence of process variables on the hydrolysis of shark muscle protein. Food Sci. Techol. Int. 4: 91-98.

Gbogouri, G. A, Linder, M., Fanni, J., and Parmentier, M. 2004. Influence of hydrolysis degree on the functional properties of salmon byproducts hydrolysates. J. Food Sci. 69: C615C622.

He, S., Franco, C., and Zhang, W. 2013. Functions, applications and production of protein hydrolysates from fish processing co-products (FPCP). Food Res. Int. 50: 289-297.

Hoyle, N. T., and Merritt, J. H. 1994. Quality of fish protein hydrolysate from Herring (Clupea harengus). J. Food Sci. 59: 7679.

Jamil, N. H., Halim, N. R. A., and Sarbon, N. M. 2016. Optimization of enzymatic hydrolysis condition and functional properties of eel (Monopterus sp.) protein using response surface methodology (RSM). Int. Food Res. J. 23(1): 1-9.

Kim, S. K., and Wijesekara, I. 2010. Development and biological activities of marine derived bioactive peptides: a review. J. Funct. Foods 2:1-9.

Kristinsson, H. G., and Rasco, B. A. 2000. Fish protein hydrolysates: Production, biochemical, and functional properties. Crit. Rev. Food Sci. Nutr. 40(1): 43-81.

Liaset, B., Nortvedt, R., Lied, E., and Espe, M. 2002. Studies on the nitrogen recovery in enzymic hydrolysis of Atlantic salmon (Salmo salar, L.) frames by Protamex ${ }^{\mathrm{TM}}$ protease Process Biochem. 37:1263-1269.

Myers, R. H., Montgomery, R. C., and Anderson-Cook, C. M. 2009. Response surface methodology, process and product optimization using design experiments, $3^{\text {rd }}$ Ed. New York: Wiley.

Nilsang, S., Lertsiri, S., Suphantharika, M. and Assavanig, A. 2005. Optimization of enzymatic hydrolysis of fish soluble concentrate by commercial proteases. J. Food Eng. 70: 571-578.

Pearce, K. N., and Kinsella, J. E. 1978. Emulsifying properties of proteins: evaluation of a turbidimetric technique. J. Agric. Food Chem. 26: 716-723.

Pires, C., Costa, S., Batista, A. P., Nunes, M. C., Raymundo, A., and Batista, I. 2012. Properties of protein powder prepared from Cape hake byproducts. J Food Eng. 108: 268-275.

Quaglia, G. B., and Orban, E. 1990. Influence of enzymatic hydrolysis on structure and emulsifying properties of sardine (Sardina pilchardus) protein hydrolysates. J Food Sci. 55: 15711573.

Ren, J., Zhao, M., Shi, J., Wang, J., Jiang, Y., Cui, C., and Xue, S. J. 2008. Purification and identification of 
antioxidant peptides from grass carp muscle hydrolysates by consecutive chromatography and electrospray ionization-mass spectrometry. Food Chem. 108(2): 727-736.

Saha, B. C., and Hayashi, K. 2001. Debittering of protein hydrolyzates. Biotechnol. Advances 19(5): 355-370.

Saidi, S., Deratani, A., Belleville, M-P., and Amar, R. B. 2014. Production and fractionation of tuna by-product protein hydrolysate by ultrafiltration and nanofiltration: Impact on interesting peptides fractions and nutritional properties. Food Res. Int. 65: 453-461.

Sathe, S. K., and Salunkhe, D. K. 1981. Functional properties of the Great Northern Bean (Phaseolus vulgaris L.) proteins: emulsion, foaming, viscosity and gelation properties. J. Food Sci. 46: $71-74,81$.

Shahidi, F., Han, X. Q., and Synowiecki, J. 1995. Production and characteristics of protein hydrolysates from capelin
(Mallotus villosus). Food Chem. 53: 285-293.

Sutanbawa, Y., and Aknes, A. 2006. Tuna process waste an unexploited resource. Infofish Int. 3: 37-40.

Taheri, A., Anvar, S. A. A., Ahari, H., and Fogliano, V. 2013. Comparison the functional properties of protein hydrolysates from poultry byproducts and rainbow trout (Onchorhynchus mykiss) viscera. Iran. J. Fish. Sci. 12(1): 154-169.

Wang, X., Yu, H., Xing, R., Chen, X., Liu, S., and Li, P. 2017. Optimization of the Extraction and Stability of Antioxidative Peptides from Mackerel (Pneumatophorus japonicus) Protein. BioMed. Res. Int. doi.org/10.1155/2017/6837285

Wangtueai, S., Siebenhandl-Ehn, S., and Haltrich, D. 2016. Optimization of the preparation of gelatin hydrolysates with antioxidative activity from Lizardfish (Saurida spp.) scales gelatin. Chiang Mai J. Sci. 43(1): 1122-1133.

\section{How to cite this article:}

Parvathy, U., P.K. Binsi, C.G. Joshy, A. Jeyakumari, A.A. Zynudheen, George Ninan and Ravishankar, C.N. 2018. Functional Hydrolysates from Yellow Fin Tuna Red Meat Using RSM Based Optimization. Int.J.Curr.Microbiol.App.Sci. 7(11): 1462-1474. doi: https://doi.org/10.20546/ijcmas.2018.711.169 